Pesq. Vet. Bras. 29(12):974-978, dezembro 2009

\title{
Hematological profile of Chelonia mydas (Testudines, Cheloniidae) according to the severity of fibropapillomatosis or its absence ${ }^{1}$
}

\author{
Silmara Rossi ${ }^{2}$, Ticiana Zwarg ${ }^{3}$, Thaís C. Sanches ${ }^{2}$, Marina de O. Cesar ${ }^{3}$, \\ Max R. Werneck ${ }^{4}$ and Eliana R. Matushima ${ }^{5}$
}

\begin{abstract}
Rossi S., Zwarg T., Sanches T.C., César M.O., Werneck M.R. \& Matushima E.R. 2009. Hematological profile of Chelonia mydas (Testudines, Cheloniidae) according to the severity of fibropapillomatosis or its absence. Pesquisa Veterinária Brasileira 29(12):974-978. Depto Patologia, Faculdade de Medicina Veterinária e Zootecnia, Universidade de São Paulo, Av. Prof. Dr. Orlando Marques de Paiva 87, Cidade Universitária, São Paulo, SP 05508-900, Brazil. E-mail: rossi.silmara@yahoo.com.br

The green turtle Chelonia mydas feeds and nests in the Brazilian coastal area and is considered an endangered species by the World Conservation Union (IUCN 2009) and threatened by the Red List of Brazilian Fauna (Ministério do Meio Ambiente 2009). Fibropapillomatosis is a disease characterized by benign skin tumors (fibropapillomas), and it is one of the main threats to the survival of this species. Studies suggest the involvement of viruses as infectious agents associated with environmental and genetic factors. Blood samples were collected from 45 turtles captured in the coastal area of the state of Sao Paulo, Brazil. From these, 27 were affected by fibropapillomas and 18 were tumor free. Biometrical data on the turtles, size, location and quantity of tumors were recorded. The area occupied by fibropapillomas per animal was calculated and four groups were determined according to severity of the disease or its absence. The objective of the study was to compare hemogram results of the sea turtles classified in these four groups. The lowest hematocrit value was observed in severely affected animals. In the hemoglobin assay, the highest value was observed in the group of tumor free turtles and the lowest, in animals severely affected. Lymphocyte counts and curved carapace length were on the verge of statistical significance.
\end{abstract}

INDEX TERMS: Chelonia mydas, green turtle, hematological profile, fibropapillomas.

RESUMO.- [Perfil hematológico de Chelonia mydas (Testudines, Cheloniidae) de acordo com o grau de acometimento pela fibropapilomatose e sua ausência.] Chelonia mydas, denominada tartaruga verde, é uma tartaruga marinha que frequenta o litoral brasileiro para alimentação e nidificação e é considerada em perigo de

\footnotetext{
${ }^{1}$ Received on August 10, 2009.

Accepted for publication on December 4, 2009

2 Programa de Pós-Graduação em Patologia Experimental e Comparada, Faculdade de Medicina Veterinária e Zootecnia (FMVZ), Universidade de São Paulo (USP), Av. Prof. Dr. Orlando Marques de Paiva 87, Cidade Universitária, São Paulo, SP 05508-900, Brazil. Autor para correspondência: rossi.silmara@yahoo.com.br

${ }^{3}$ Iniciação Científica, FMVZ-USP, São Paulo, SP.

${ }^{4}$ Projeto Tamar-lbama Base Ubatuba/SP, Ruas Antonio Atanázio 273, Itaguá, Ubatuba, SP 11680-000, Brazil.

${ }^{5}$ Departamento de Patologia, FMVZ-USP, São Paulo, SP.
}

extinção pela IUCN (World Conservation Union, 2009) e ameaçada pela Lista Vermelha da Fauna Brasileira (Ministério do Meio Ambiente, 2009). A fibropapilomatose, doença caracterizada por tumores cutâneos benignos (fibropapilomas), é uma das mais importantes ameaças à sobrevivência dessa espécie. Pesquisas sugerem o envolvimento de agentes infecciosos virais em associação com fatores ambientais e genéticos. Foram colhidas amostras sanguíneas de 45 tartarugas provenientes do litoral do estado de São Paulo, Brasil, sendo 18 sem fibropapilomas e 27 acometidas. Dados de biometria das tartarugas, quantidade, localização e tamanho dos tumores foram anotados. Foi realizado o cálculo da área de fibropapilomas por animal e foram estipulados 4 grupos de acordo com o grau de acometimento e sua ausência. O objetivo foi realizar uma comparação entre os hemogramas das tartarugas marinhas classificadas nos 4 grupos. Ani- 
mais de grau grave apresentaram o menor valor para hematócrito. Para dosagem de hemoglobina, observou-se que o maior valor foi para o grupo de tartarugas sem fibropapilomas e o menor para o de grau grave. Os valores de linfócitos e comprimento curvilíneo da carapaça beiraram a significância estatística.

TERMOS DE INDEXAÇÃO: Chelonia mydas, tartaruga verde, perfil hematológico, fibropapilomas.

\section{INTRODUCTION}

Humans and turtles have been connected for a long time, since the men settled up in coastal areas and began several activities in the ocean. During countless generations, coastal communities depended on sea turtles and their eggs to obtain protein and other products. In many regions, turtle hunting is still practiced (Eckert et al. 2000). During the 20th century, predatory hunt of these animals considerably contributed for reducing the population of several species.

Sea turtles have important ecological functions, and are vital for the balance of the marine ecosystem, contributing for the health and maintenance of coral reefs, estuaries and sandy beaches (Eckert et al. 2000). Therefore, when they are protected, so are the seas and coastal areas (Frazier 1999). However, this aim may only be achieved with conservation and management plans that revert many years of population reduction.

Data on fibropapillomatosis in sea turtles suggest a viral origin (Herbst et al. 1998). However, demographic development, industrial and agronomic activities in sites located near beaches, bays and lakes may contribute for the increase in the incidence of the disease (Balazs 1991; Adnyana et al. 1997). The influence of environmental factors in the occurrence of the disease was also considered after studies carried out in Florida (Ehrhart 1991) and Hawaii (Balazs 1991). A study carried out in Baja California indicates that the effects of the economical development on coastal and marine ecosystems are still unknown (Gardner et al. 2003). Fibropapillomatosis is known to be related to the action of an alpha-herpesvirus called chelonid FP-associated herpesvirus (C-FP-HV), present in $100 \%$ of the natural occurrences and in $100 \%$ of the tumors induced by the inoculation of turtles kept in captivity (Ene et al. 2005). According to Brown, Lackovich and Klein (1999), chelonian herpesvirus associated to fibropapillomas in Chelonia mydas, Caretta caretta and Lepidochelys olivacea is a likely candidate for fibropapillomatosis etiological agent. For Herbst and Klein (1995) it is clear that the primary etiological agent in fibropapillomatosis is an infectious agent.

Fibropapillomas (Fig.1) is a benign tumor that can achieve $30 \mathrm{~cm}$ of diameter (Lackovich et al., 1999) and it can involve the tegument being able to be in fins, eyes, base of the tail, oral regions, cervical, inguinal, axillary, carapace and cloacal (Herbst 1994, Jacobson et al. 1989). The disease is characterized by the presence of internal

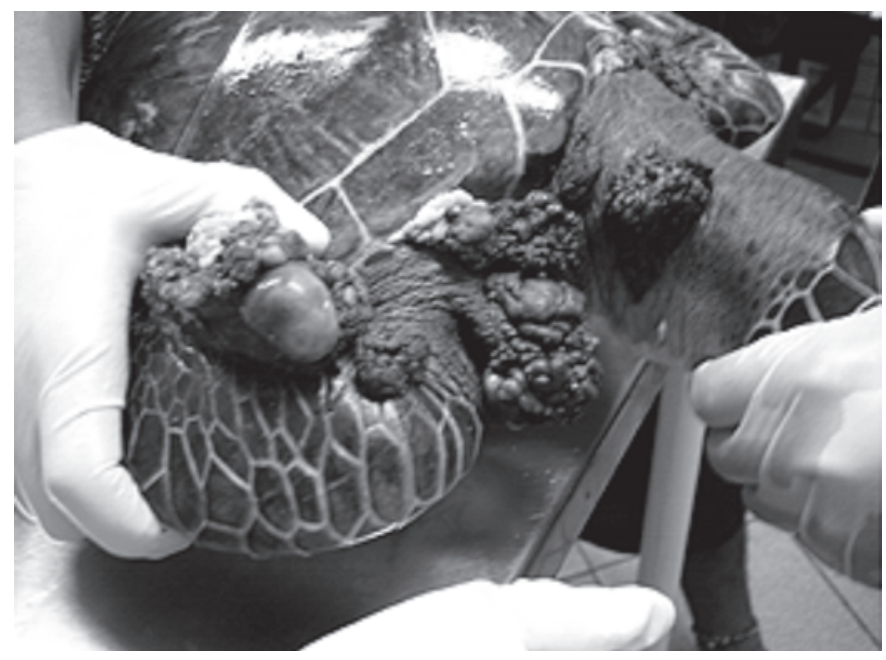

Fig.1. Fibropapillomas in the green turtle, Chelonia mydas.

and external tumors (Herbst 1994). The lesions caused by fibropapillomas can interfere with the hydrodynamics and locomotion of these animals, compromising the feeding (Adnyana et al. 1997), being debilitanting and fatal (Aguirre et al. 1998).

In Brazil, the first studies carried out in order to better understand the etiology of the tumors in sea turtles employed histopathological, immunohistochemical, ultrastructural, hematological and biochemical analyses (Matushima et al. 1999, 2001, Matushima 2003). After, studies were made by Rossi (2007) for blood profile examination and leukocytes function analysis, colleting blood samples from turtles with and without tumors.

The evaluation of hematological conditions of sea turtles using a complete hemogram is extremely important, both in healthy animals and in those affected by different degrees of fibropapillomatosis.

\section{MATERIALS AND METHODS}

Turtles, forms and sites of capture

Green turtles, Chelonia mydas (Linnaeus, 1758), used in the present trial were captured at different beaches in the city of Ubatuba, located in the Northern seaside of the state of Sao Paulo, Brazil (Latitude 45, 26', 13" S. Longitude 45, 4'W). This region was selected due to the constant presence of young green turtles feeding in the coastal area. Occasionally, some turtles were captured in beaches of other regions, such as Guarujá, SP (Latitude: $24^{\circ}, 02^{\prime}$ S. Longitude: $46^{\circ}, 25^{\prime}$ W), São Sebastião, SP (Latitude: $23^{\circ}, 50^{\prime} \mathrm{S}$. Longitude: $45^{\circ}, 18^{\prime} \mathrm{W}$ ), and Ilha Bela, SP (Latitude: $23^{\circ}, 46^{\prime} \mathrm{S}$. Longitude: $45^{\circ}, 21^{\prime} \mathrm{W}$ ). Only one specimen was captured in captivity by the Ibama in the city of Paraty, RJ (Latitude: 23, 13', 04" S. Longitude: 44, 42', 47' W).

Turtles were incidentally captured in fishing nets or stuck on the beach and were taken to the technicians at Projeto TamarIbama, Ubatuba/SP Base. After being captured, animals were kept in captivity until they were fit to be released again.

Biometrical data were collected from each animal, such as body mass (BM), curved carapace length and width (CCL and CCW, respectively) and curved plastron length and width (CPL and CPW, respectively). Besides, the absence or presence of fibropapillomas, 
as well as their quantity, size and location were also recorded. Fibropapilloma area per animal (sum of the areas of each tumor) was determined, leading to a classification in four groups.

The sex of the turtles was not determined because animals did not show external sexual dimorphism.

\section{Collection of blood samples}

Blood samples were collected from 45 specimens, 27 of them affected and 18 of them unaffected by fibropapillomas. The cervical venous sinus was punctured for blood collection, using the occipital bone as the reference for its location. Around $10 \mathrm{~mL}$ of blood were drawn from each animal, and samples were placed in identified tubes containing sodium heparin $\mathrm{BD}^{\circledR}$. Tubes were kept under refrigeration until analyzed at the Faculdade de Medicina Veterinária e Zootecnia at Universidade de São Paulo (FMVZ-USP). The aliquot to be used in blood extensions was placed in a tube without any anticoagulant agent. The interval between collection and analysis of the samples was no longer than 24 hours.

\section{Analysis}

Blood samples were tested as follows: Hematocrit $(\mathrm{Ht})$ by the technique for determination of microhematocrit, using a microcentrifuge. Total counts of red blood cell (Eritr) and white blood cell (Leu) were performed in a Neubauer chamber, using Natt \& Herrick (1952) diluent. Leukocyte count was carried through the blood smears made at the time of collection of blood samples, stained with May-Grünwald-Giemsa technique (Rosenfeld 1947); the reading was held in the optical microscope objective lens of $100 \mathrm{X}$. The technique that was used to count Thrombocytes (Thromb) was performed by counting the number of these cells in 1000 erythrocytes counted. Hemoblobin assay (Hb) was determined by commercial Labtest ${ }^{\circledR}$ kit. Plasma proteins (PI prot), using a refractometer and the erythrocyte indices (MCV: mean cell volume; $\mathrm{MCH}$ : mean corpuscular hemoglobin; $\mathrm{MCHC}$ : mean corpuscular hemoglobin concentration) were calculated from the total count of erythrocytes, hematocrit and hemoglobin.

\section{Statistical analysis}

Kruskal-Wallis non-parametric test were used in the statistical analysis of the results.

\section{RESULTS}

The macroscopic evaluation of the fibropapillomas showed that colors varied from pink to black, texture from smooth to wart-like, and size from 0.2 and $13.0 \mathrm{~cm}$. The amount of fibropapillomas per animal ranged from 2 to129.

Animals were grouped according to the absence of fibropapillomatosis (Group 0) and its presence in different levels (Group 1 to 3 ).

Animals affected were divided into three groups according with the severity of the disease (Table 1): 1 (slightly affected, up to $50 \mathrm{~cm}^{2}$ ), 2 (moderately affected,

Table 1. Areas of fibropapillomas

\begin{tabular}{ccc}
\hline Turtles & Quantity & Area $\left(\mathrm{cm}^{2}\right)$ \\
\hline T1 & 12 & 2.90 \\
T2 & 63 & 181.82 \\
T6 & 84 & 146.53 \\
T9 & 23 & 222.13 \\
T10 & 16 & 16.75 \\
T11 & 85 & 17.99 \\
T14 & 5 & 1.72 \\
T15 & 33 & 131.76 \\
T16 & 66 & 207.54 \\
T18 & 13 & 49.30 \\
T19 & 38 & 120.46 \\
T20 & 39 & 135.01 \\
T21 & 106 & 113.23 \\
T22 & 34 & 105.27 \\
T23 & 30 & 81.68 \\
T24 & 16 & 28.51 \\
T29 & 4 & 0.93 \\
T30 & 37 & 98.31 \\
T31 & 17 & 24.19 \\
T34 & 10 & 21.83 \\
T39 & 57 & 113.73 \\
T40 & 129 & 62.63 \\
T41 & 36 & 64.96 \\
T42 & 84 & 117.09 \\
T43 & 70 & 239.10 \\
T45 & 2 & 13.08 \\
T46 & 78 & 51.99 \\
T4 &
\end{tabular}

Table 2. Groups of green turtles affected and unaffected by fibropapillomas, captured in the coastal area of the state of Sao Paulo, from August 2005 to November 2006, according to the severity of the disease

\begin{tabular}{ccccc}
\hline Parameters & $0(\mathrm{n}=18)$ & $1(\mathrm{n}=10)$ & $2(\mathrm{n}=5)$ & $3(\mathrm{n}=12)^{*}$ \\
\hline $\mathrm{CCL}(\mathrm{cm})$ & $36.47 \pm 1.00$ & $44.95 \pm 3.75$ & $48.5 \pm 5.78$ & $44.25 \pm 2.13$ \\
$\mathrm{Ht}(\%)$ & $24.63 \pm 2.63$ & $24.6 \pm 1,98$ & $26 \pm 6.25$ & $22.75 \pm 2.23$ \\
Eritr $\left(10^{5} / \mathrm{mm}^{3}\right)$ & $3.69 \pm 0,52$ & $3,80 \pm 0.31$ & $4.65 \pm 0.95$ & $4.34 \pm 0.60$ \\
Leu $\left(/ \mathrm{mm}^{3}\right)$ & $5545.45 \pm 1152.97$ & $5300 \pm 720.2$ & $5125 \pm 1532.63$ & $7125 \pm 1267.49$ \\
$\mathrm{Hb}(\mathrm{g} / \mathrm{dL})$ & $7.11 \pm 0.71$ & $6.94 \pm 0.61$ & $7.10 \pm 1.59$ & $6.41 \pm 0.68$ \\
$\mathrm{MCV}(\mathrm{fL})$ & $61.82 \pm 8.30$ & $65.77 \pm 4.13$ & $56.01 \pm 4.71$ & $62.6 \pm 7.65$ \\
$\mathrm{MCH}(\mathrm{pg})$ & $21.79 \pm 3.25$ & $18.55 \pm 1.48$ & $15.38 \pm 1.15$ & $17,47 \pm 2,10$ \\
$\mathrm{MCHC}(\mathrm{g} / \mathrm{dL})$ & $29.41 \pm 0,97$ & $27.99 \pm 0.52$ & $27.54 \pm 0.42$ & $28.5 \pm 1.49$ \\
$\mathrm{Pl} \mathrm{prot}(\mathrm{g} / \mathrm{dL})$ & $4.05 \pm 0.35$ & $5.20 \pm 0.21$ & $6 \pm 0.46$ & $4.87 \pm 0.28$ \\
Het $\left(/ \mathrm{mm}^{3}\right)$ & $4316.36 \pm 1043.5$ & $4939 \pm 886.07$ & $7487.5 \pm 706.58$ & $4266.25 \pm 1043.14$ \\
Eos $\left(/ \mathrm{mm}^{3}\right)$ & $171.81 \pm 26.01$ & $213.5 \pm 63.68$ & $385 \pm 182.68$ & $123.7 \pm 48.53$ \\
Mon $\left(/ \mathrm{mm}^{3}\right)$ & $258,18 \pm 58,74$ & $341 \pm 82.21$ & $813.75 \pm 359.13$ & $360.83 \pm 77.97$ \\
Lin $\left(/ \mathrm{mm}^{3}\right)$ & $799.09 \pm 163.12$ & $856.5 \pm 149.36$ & $1438.7 \pm 652.02$ & $974.16 \pm 203.77$ \\
Thromb $\left(10^{3} / \mathrm{mm}^{3}\right)$ & $16.5 \pm 3.08$ & $11.30 \pm 1.88$ & $22.83 \pm 5.22$ & $16.16 \pm 1.76$ \\
\hline
\end{tabular}

Results are presented as means \pm standard deviation. *One turtle from group 3 was not included in the statistical analysis of thrombocyte and differential leukocyte count. 
from 51 to $100 \mathrm{~cm}^{2}$ ), and 3 (severely affected, above $101 \mathrm{~cm}^{2}$ ). The number of thrombocytes and the differential count could not be carried out in one affected animal, because there were few cells in the blood extension, preventing its analysis. Hemogram and leukogram values for all animals are shown in Table 2.

\section{DISCUSSION}

As for the size of the animals (CCL), the lowest means were observed in unaffected animals. The lowest hematocrit value was observed in severely affected animals. In the study by Work \& Balazs (1999), there was a progressive decrease from score 0 to 3 . No progressive decrease in absolute leukocyte counts were observed, but there was an increase in score 3 . In the hemoglobin assay, the highest value was observed in the group of tumor free turtles and the lowest, in animals severely affected. Mean corpuscular volume (MCV) was greater in score 1 and mean corpuscular hemoglobin $(\mathrm{MCH})$ progressively decreased from unaffected animals to those moderately affected and increased in the severely affected ones. Mean corpuscular hemoglobin concentration (MCHC) was almost unchanged by the presence or absence of the disease. There was a progressive increase in the concentration of plasma protein concentration from score 0 to 2 and a decrease in score 3 . Tumor free animals and those slightly affected showed lower absolute eosinophil counts, whereas animals moderately affected showed higher counts, different from the suggestion by Work \& Balazs (1999): a progressive decrease in eosinophil counts as the severity of the disease increased. Statistical analysis showed no significant differences between four groups according to the severity of fibropapillomatosis or its absence. It is important to emphasize that there are many factors that can affect the values of the hematological profile and consequently the cellular function of sea turtles, such as anatomic site of venipuncture; age of the turtles; mechanism of thermoregulation, sex (McArthur et al. 2004). However, the interference of these factors was not evaluated in this work.

Fibropapillomatosis remains unclear in spite of the countless studies carried out all over the world. This situation causes concern, once this disease in considered one of the main causes in the reduction of Chelonia mydas population. It should be considered that young turtles affected may not survive and may not contribute to the preservation of the species.

The ever-growing environmental imbalance is one of the main responsible factors for the loss of animal habitats and this loss is the main cause of species extinction. Diseases possibly related to pollution, such as fibropapillomatosis, are another relevant factor in the reduction of animal populations and consequently in the increase in the severity of ecosystem imbalance.

It is necessary to increase the number of $C$. mydas with or without fibropapillomas evaluated in future studies in order to obtain more concrete and relevant results.
Acknowledgements.- To Projeto Tamar-lbama, Ubatuba/SP Nase, Departamento de Patologia da Faculdade de Medicina Veterinária e Zootecnia, Universidade de São Paulo (VPT-FMVZ/USP), CAPES for the Master's degree Grant, and FAPESP for financial support.

\section{REFERENCES}

Adnyana W., Ladds P.W. \& Blair D. 1997. Observations of fibropapillomatosis in green turtles (Chelonia mydas) in Indonesia. Aust. Vet. J. 75(10):737-742.

Aguirre A.A., Spraker T.R., Balaz G.H. \& Zimmerman B. 1998. Spirorchidiasis and fibropapillomatosis in green turtles from Hawaiian Islands. J. Wildl. Dis. 34(1):91-98.

Balazs G.H. 1991. Current status of fibropapillomas in the Hawaiian green turtle, Chelonia mydas, p.47-57. In: Balazs G.H. \& Pooley S.G. (Eds), Research Plan for Marine Turtle Fibropapilloma. U.S. Department of Commerce, National Oceanographic and Atmospheric Administration, National Marine Fisheries Service. NOAA-TM-NMFSSWFSC 156.

Brown D.R., Lackovich,J.K. \& Klein P.A. 1999. Further evidence for the absence of papillomaviruses from sea turtle fibropapillomas. Vet. Rec. 145:616-617.

Eckert K.L., Bjordnal K.A., Abreu-Grobois F.A. \& Donnelly M. 2000. Técnicas de Investigación y Manejo para la Conservación de las Tortugas Marinas. Vol.4. Consolidated Grafic Communications, Pennsylvania. 265p.

Ehrhart L.M. 1991. Fibropapillomas in green turtles of the Indian River lagoon, Florida: Distribution over time and area, p.59-61. In: Balazs G.H. \& Pooley S.G. (Eds), Research Plan for Marine Turtle Fibropapilloma. U.S. Department of Commerce, National Oceanographic and Atmospheric Administration, National Marine Fisheries Service. NOAA-TM-NMFS-SWFSC 156.

Ene A., Su M., Lemaire S., Rose C., Schaff S., Moretti R., Lenz J. \& Herbst L.H. 2005. Distribution of chelonid fibropapillomatosis associated herpesvirus variants in Florida: Molecular genetic evidence for infection of turtles following recruitment to neritic developmental habitats. J. Wildl. Dis. 41(3):489-497.

Frazier J. G. 1999. Conserving sea turtles and other natural resources. Proc. 13th Annual Symposium on Sea Turtle Biology and Conservation, Georgia, p.23-27.

Gardner S.C., Pier M.D., Wesselman R. \& Juárez J.A. 2003. Organochlorine contaminants in sea turtles from the Eastern Pacific. Marine Pollution Bulletin 46:1082-1089.

Herbst L.H., Greiner E.C., Ehrhart L.M., Bagley D.A. \& Klein P.A. 1998. Serological association between spirorchidiasis, herpesvirus infection, and fibropapillomatosis in green turtles from Florida. J. Wildl. Dis. 34(3):496-507.

Herbst L.H. \& Klein P.A. 1995. Green turtle fibropapillomatosis: Challenges to assessing the role of environmental cofactors. Environ. HIth Perspect 103(4):27-30.

Herbst L.H. 1994. Fibropapillomatosis of marine turtles. Annu. Vet. Fisheries Dis. 4:389-425.

IUCN 2006. Red List of Theatened Species. Disponível em <http: // www.iucnredlist.org>. Acesso em 15 mar. 2009.

Jacobson E.R., Mansell J.L., Sundberg J.P., Hajjar L., Reichmann M.M., Ehrhart L.M., Walsh M. \& Murru F. 1989. Cutaneous fibropapillomas of green turtles (Chelonia mydas). J. Comp. Pathol. 101:3952.

Lackovich J.K., Brown D.R., Homer B.L., Garber R.L., Mader D.R., Moretti R.H., Patterson A.D., Herbst L.H., Oros J., Jacobson E.R., Curry S.S. \& Klein P.A. 1999. Association of herpesvirus with fibropapillomatosis of the green turtle Chelonia mydas and the loggerhead turtle Caretta caretta in Florida. Diseases of Aquatic Organisms 37:8997.

Pesq. Vet. Bras. 29(12):974-978, dezembro 2009 
McArthur S., Wilkinson R. \& Meyer J. 2004. Medicine and Surgery of Tortoises and Turtles. Blackwell Publishing, Malden, MA.

Matushima E.R. 2003. Fibropapilomas em tartarugas marinhas: aspectos histológicos, imuno-histoquímicos e ultra-estruturais. Tese de Livre-Docente em Patologia, Faculdade de Medicina Veterinária e Zootecnia, USP, São Paulo. 111p.

Matushima E.R., Longatto-Filho A., Di Loretto C., Kanamura C.T., Ramos M.C.C., Sinhorini I.L. \& Gallo B. 2001. Cutaneous papillomas of green turtles: A morphological, ultrastructural and immuno-histochemical study in brazilian specimens. Braz. J. Vet. Res. Anim. Sci. 38(2):51-54.

Matushima E.R., Longatto-Filho A., Di Loretto C., Kanamura C.T., Gallo B. \& Baptistotte C. 1999. Cutaneous papillomas of green turtles: a morphological and immunohistochemical study in Brazilian specimens. Proc. $19^{\text {th }}$ Annual Symposium on Sea Turtle Conservation and Biology, South Padre Island, Texas, p.237-239. U.S. Dept. Commerce NOAA Tech. Memo. NMFS-SEFSC 443.
Ministério do Meio Ambiente (Brasil): Livro Vermelho da Fauna Brasileira Ameaçada de Extinção. Disponível em <http://www.mma.gov.br>. Acesso em 14 mar. 2009.

Natt M.P. \& Herrick G.A. 1952. A new blood diluent for counting erythrocytes and leukocytes of the chicken. Poultry Sci. 31:735738.

Rosenfeld G. 1947. Método rápido de coloração de esfregaços de sangue: noções práticas sobre corantes pancromáticos e estudo de diversos fatores. Mem. Inst. Butantan 20:315-328.

Rossi S. 2007. Estudo do impacto da fibropapilomatose em Chelonia mydas Linnaeus, 1758 (Testudines, Cheloniidae). Dissertação de Mestrado em Ciências, Faculdade de Medicina Veterinária e Zootecnia, USP, São Paulo. 104p.

Work T.M. \& Balazs G.H. 1999. Relating Tumor score to hematology in green turtles with fibropapillomatosis in Hawaii. J. Wildl. Dis. 35(4):804807. 